\title{
CONSTRUCTS OF DEVELOPMENT FROM INSIDE THE DEVELOPMENT COMMUNICATION SYLLABI
}

\author{
Jonalou S. Labor* \\ College of Mass Communication, University of the Philippines Diliman, \\ Quezon City, Metro Manila, Philippines \\ email: jslabor@up.edu.ph
}

Published online: 15 July 2017

To cite this article: Labor, J. S. 2017. Constructs of development from inside the Development Communication syllabi. International Journal of Asia Pacific Studies 13 (2): 23-44, https://doi.org/10.21315/ijaps2017.13.2.2

To link to this article: https://doi.org/10.21315/ijaps2017.13.2.2

\begin{abstract}
Discourses of development in academic institutions must be thoroughly investigated. Using a set of Development Communication (DevCom) syllabi and the theories of Xu Xiaoge (2009) and Arturo Escobar (1995), this paper qualitatively investigated on the nature and process of the constructed discourse of development in an academic setting from sample course syllabi content, topics and activities. Results have shown that the syllabi's content and discourse are either pro-process or pro-participation development. Moreover, the set of studied syllabi have not actively articulated the post-development paradigm. The research suggests that faculty members who teach the course revisit the constructs of DevCom by constantly including development in the content, putting the discourse of alternatives to development, and theorising on the paradigm of development communication to further establish the field.
\end{abstract}

Keywords: Development discourse, academic institutions, development communication, syllabus

\section{INTRODUCTION}

Universities and colleges have offered courses and programs that are aimed to understand and provide solutions to poverty issues in local and global settings. Some have taken the economic route in asserting development while others in the academe believe that there are other ways than economic programs 
to boost well-intentioned development (Lagerway 1990; Colle 2008). Hence, development should be seen as a total approach where development agencies and the target communities must communicate in order to reach real development (Servaes 2002; Librero 2008). Everett Rogers (1976 in Servaes 2008) emphasised this role of development communication in the agenda for social change, claiming that communication knowledge and research will advance social and material development. If there are trained development communicators, they could serve as vital partners in enforcing change within communities. Development Communication (DevCom) education is seen as a vital ingredient in identifying, processing and assisting the needs of the people (Quebral 2012).

In various parts of the world, the need for development communicators as specialists in understanding local problems on social change is on the rise. As early as the 1970s, modules on DevCom have been problematised in various parts of the world. In Africa, for instance, learning the content of the DevCom program means intensifying interpersonal, mass media and integrated approaches that require know-how in extension and community development method as well as ideological and mass media mobilisation techniques (Moemeka in Boafo 1991). A decade after, Waisbord (2001), in recognising the role of DevCom in the development agenda put forward a list of strategies and techniques that are essential in teaching and learning the field. From "tool kit strategies" to participatory communication rituals, Waisbord emphasised the need for a stable set of teaching and learning plan to aid in the education of development communicators. In India, communication experts undergo extensive trainings so they can enhance knowledge and understanding of communication interventions to combat poverty (Thomas 2008). Colle (2008) argued that teaching practitioners about communications for development will help solve the problems of designing, planning, executing and evaluating development projects. Various publications have also been developed to look into communication strategies in learning the science of development communication (White 2004; Mefalopulos 2008; Singhal and Rogers 2012).

Learning DevCom from inside the classroom can be attributed to a curriculum that strongly advocates for social change. Palmer, Bach and Streifer (2014) argue that a properly designed curriculum, as seen in the curriculum's set of learning-centred syllabi, accounts for how much content is absorbed by the students. Literature has also argued that significant learning occurs when teachers and academic administrators see the syllabi as a kit for engaging students in cognitive, affective and self-directed learning (Fink 2013; Anderson et al. 2001). This means that the framing and content of syllabi aid in the approaches of how academic programs are taught and learned. 
In the Philippines, Development-related academic programs abound. Higher education institutions offer a variety of degrees in both the undergraduate and the graduate schools in areas like Development Studies, Development Education, Development Ecology, and Development Communication. These offered programs have been put in place to provide venues in discussing, debating, transforming, critiquing, and hopefully, providing alternatives to the discourse of development in the country and the world (Librero 2008; Rolle 2016). Along with the institutionalisation of development in various academic settings, discourses of development have been constructed in academic institutions to represent various goals, roles, challenges and sometimes, even myths about how countries can become better providers for their citizens (Lundell and Higbee 2001). Most often than not, the discourses discussed and taught in academic institutions have used the vantage point of development scholars, aid donors, workers, practitioners and even critics of "development." Students are lectured on the development discourse, with the promise that there is solution to some societal harm. Development is academically delivered with a positive language, to change individuals and organisations, with a promise and an attempt to eradicate social ills and lessen social divide.

For example, the University of the Philippines College of Development Communication hopes to provide a healthy academic soil for this kind of discourse. DevCom has been hailed as one of the Philippines' bests. The Philippines' Commission on Higher Education has awarded it as the country's Center of Excellence in Development Communication education. Moreover, it received an accreditation as ASEAN's best academic programs, having passed the external quality assurance guidelines (Niedermeier and Pohlenz 2016). Its founding mother, Nora Quebral, articulates in a primer on DevCom that the program mediates in the transitioning of individuals from poverty to growth, "via equity and the unfolding of individual potential" (2012: 3). Armed with strengths on research and practice, DevCom embarked on a journey to provide meaningful ways to uplift the human being from its current state. Guided by the discourse of change, it promises to train students in the area of human communication as agents to the promises of development.

The program has problematised development since its conception in 1971. It has articulated its brand of development as an evolving concept. Seen as co-existing with its history and organisational structure, development in the DevCom language has been constructed in terms of economic, social, political, and moral contexts. In a research conducted by Cagasan et al. (2008), it was found that the notions of development among development communicators go along with how they practice their roles as development mediators. The 
research reveals that graduates and undergraduate researches, as well as the faculty members, see development as improvement, a goal and a process. These themes emerge when the academic unit is transformed from a department, an institute and to a college, respectively.

The discourse of development that DevCom claims can be learned formally inside the classroom, in different modes and vantage points. Quebral (2012) states that DevCom has evolved from an art and science course in 1971 to a completely scientific discipline of human communication. Although this has not been philosophically articulated in the literature, experts and academics have begun to ask the meta-frame in DevCom (Librero 2008; Cagasan et al. 2008; Lundell and Higbee 2001). One asks: Which epistemology, ontology and axiology do DevCom participate?

This seems to suggest that through time, there have been different ways of how development has been mediated inside the DevCom classroom. Furthermore, inside the bulwarks of the academic classroom, perceived "experts" such as teachers create development discourse. Development may have been given various constructions as this can be defined and characterised in various ways, in different academic settings (Lawrence 2008). Librero, reflecting on how he has approached the academic component of DevCom when he was a teacher in the College, mentioned that there are still challenges on how the field can be maximised since the transition of the program from Agricultural Communication to its "expanded playing field called development" (Librero 2008: 188).

Given these diverse realities on how the discourse of development is constructed in various disciplinal platforms, this qualitative research asks the question: What frames of development are constructed in the select group of syllabi from the Department of Development Journalism, College of Development Communication at the University of the Philippines Los Banos?

There is a return to a generalist curriculum to the DevCom program at UP Los Banos (College of Development Communication [CDC] 2015). With this shift in mindset to create a holistic graduate who has a scientific mind and that has the various skills in interpersonal communication, there is a move to align all allied disciplines of journalism, broadcasting, and the like to this "packaged" graduate/practitioner. It would be interesting to problematise, therefore, how development and communication are described using the course objectives, topics, activities and references.

Moreover, the Department of Development Journalism - which has gratefully accepted the invitation to be the locale for the paper-aims to help achieve the program's goal. Based on CDC's website, the department 
is said to be focused on schooling the students in development news for print and electronic media. Additionally, the department wants "to provide a training ground for development journalists who will uphold the ideas and standards of journalism instruction, research and extension. It also aims to promote ethical, systematic, and research-based development journalism" (Department of Development Journalism 2015). Furthermore, as the study's site, the department's faculty members are acclaimed to the specialisation by virtue of expertise and education as most of the faculty members have either a Master of Science or a PhD in Development Communication (College of Development Communication 2015).

\section{LITERATURE REVIEW}

\section{Academic Institutions as Sources of Discursive Power}

Institutions, like universities and colleges, have the power to affect behaviours, beliefs, and opportunities of individuals, groups, organisations and societies (Lawrence 2008: 170). With the way institutions command the ways in which practices are learned, exercised and accepted, repetitions in commands allow for the activation of certain standards and acceptable traditions. In the context of schools, for example, the way that a specific course is taught may lead to the way students see the world. The social construction of certain realities by the teachers relate to how students see such realities in their everyday lives. In effect, just like how Lawrence (2008) has argued that organisational structures and processes reinforce certain beliefs and practices, academic institutions can facilitate how certain ideologies are learned, adopted and practiced by its learners to both reduce uncertainty on a matter and legitimise one's grasp of the field. It appears that if certain types of discourses are constantly being presented to certain institutions such as schools, then these discourses are legitimised, accepted and sadly, at times, blindly followed.

In fact, the discourse of development has been strongly reinforced that it paved the way for a collection of words that are strongly associated with the development agenda. Cornwall and Eade (2010) published a book that looks at how various development buzzwords and fuzzwords have shaped the discourse of development and aid projects in the world. Quite intriguingly, though, they also mentioned that the buzzwords "are defined by the cultural mindsets of donor agencies, be they bilateral or multilateral (and hence nominally pluricultural)" (Cornwall and Eade 2010: VII). This suggests that because there is a 
repetition of concepts in the development sphere, there can also be stagnation on the field. To bring the level of discussion inside the classroom, therefore, would this affect the academic discussions on development? If repetitive buzz and fuzz words in development reaches the class via references and topics, what kind of development scholars are produced in the academic world? Moreover, Rist (in Cornwall and Eade 2010) asserted that development still has been elusive and fuzzy despite its prevalent use. He argued that, "The survival of the planet will depend upon abandoning the deep-rooted belief that economic growth can deliver social justice, the rational use of environment, or human well-being, and embracing the notion that there would be a better life for all if we moved beyond development" (19).

The chapter further concludes that it is high time to discard the development buzzword, especially if it is defined outside social practice. Interestingly, the author leaves the challenge to think of a life outside development, as its definitions are more likely constructed from the mindsets of the privileged regions more than its perceived beneficiaries. Perhaps the challenge can be better felt by the academe as these buzz and fuzz words are constantly introduced, articulated and repeated in various classrooms and hallways. Furthermore, the article seems to suggest that throughout history, the concept of development has been studied and taught a lot but has not solved the alarming problems at hand.

How is development spoken among the intellectual circles? Della Faille (2011) analysed the discourses of authors who have studied development in order to see how the concept has been discussed in development circles. Suggestive of the notion that development is positively expressed as a saviour rather than a problem, he assessed how the sentiments of authors such as Mohanty, Escobar, Scott, Ferguson, Rist and a selection of gender studies scholars have been integrated in the discipline. Della Faille (2011) mentions that since the cited authors have a shared denunciation of conventional analysis of underdevelopment, then their perspectives have remained marginalised as these types of discourses are seen as critiques and not as alternatives to the development discourse. Given all these historically worthy claims and accounts about the discourse of development, what kind of development discourses are constructed, taught, and legitimised inside the course syllabi?

\section{Teaching and Mediating Development through Communication Education}

The process of mediating the discourses of development via academic institutions should be analysed as the teaching of the concepts of development strongly lead to how development is written, reported, and received by certain 
stakeholders. Djokotoe (2013), arguing from the standpoint "development stories are big news for developing countries" (2) wrote ten practical tips for young communicators in the coverage of development. He stressed that simplicity in the approach to writing development news must be a key consideration. He furthered that since students are penning for ordinary people and not "experts," reports and stories must be broadened, humanised, ordinarypeople focused, seen from an unusual angle, reported from the field, have used news events to explain issues, avoided technical jargons, have carefully used statistics, followed up stories, and journalists must have read widely about the issue.

But is the teaching of DevCom really as simple as the practical tips mentioned above? It seems that the practice of DevCom has been varied as the problems about development. From Africa to Asia to Latin America, the coverage of development led to a variety of communication and journalistic practices. At times, the approach has been investigative while for others, it has been considered an ally of the government (Edeani 1993). Researches also have shown that, in terms of development journalism in particular, dysfunctional schools have led to less job knowledge and satisfaction in the practice of the profession (Domatob and Hall 1983: 25-27; Grossenbacher 1988: 142-162). This is often the case especially since there is no clear line that separates DevCom from Mass Communication. Perhaps a more fitting question would be: Is there really a difference between the two?

Furthermore, thinking that DevCom and its allied fields such as Development Journalism (DevJourn) is a bow to modernity exists in the literature. DevJourn stemmed from the desire of "media experts, development professionals and theorists, working within the modernisation framework, to view the role of newspapers in the national development process" (Pakistan Higher Education Commission n.d.). Interestingly, the notion of DevJourn has led to two strands of historical accounts. The first strand stems from the western style of investigative journalism while the second type is anchored on the benevolent-authoritarian model (Wimmer and Wolf 2005). Academic institutions that cater to DevJourn appear to teach and frame their interpretations of the nature, function, and relevance of development journalism in reference to two perspectives: the source of the development fund and the needs of their communities and stakeholders. If this is the case for the specialist track that is DevJourn, is this the same reality for a generalist DevCom? If this is so, then, is DevCom an ally of modernity or a critic of modernisation? These questions are important since the way the program is molded would shape the ways in which the course content will be delivered. 
Furthermore, in countries which have strong media devoted to the investigative traditions, development communication is perceived as an alternative to the way government reports its inflated development affairs. Specifically, DevJourn is strongly associated with social relevance and an advocacy for reporting economic development. Quebral (Pakistan Higher Education Commission n.d.: 134), mentioned that this type of journalism is "meant to fight economic and social problems with information coming largely from science." This has been strongly supported by Wimmer and Wolf (2005) when they claimed that the field of development journalism has a central social objective but differs to that of Quebral's notion of a uniform path of development by incorporating modernisation and a global sense of community. Both, however, agree that development journalism has been practiced more in the Southern hemisphere and the Third World by reporting on the living standards of the rural and developing regions of the world.

Previous studies have provided topical categories to distinguish the field from other journalistic endeavours. Accounts have shown that topics of concerns for development journalism include but are not limited to agricultural development, education and literacy, family planning, health, scientific and technical development, mass media, national integration, rural and urban development, among others (Vilanilam 1975). Other researchers, however, claim that to distinguish the field from other journalistic practices through coding of topics does not create an accurate picture of the principles of development journalism.

In a different light, Romano (in Xiaoge 2009) also tried to categorise development journalism into the types of journalists who create the practice that is development journalism. The author named the journalists as "nation builders, as government partners, as agents of empowerment, as watchdogs and as guardians of transparency" (7). Because of the problematic manner in naming development journalism, efforts have been made in defining the field by looking at the source of information, the actors presented in the news, and the orientation to which these news are treated (Xiaoge 2009).

\section{Teaching Development Communication}

The value of communication for development approaches in both governmental and non-governmental agencies must be taught in both formal and informal manners (Servaes 2008; Wahl-Jorgensen and Hanitzsch 2009). Learners of development communication, particularly of development journalism, must be acquainted with the changing relationships between practitioners and educators (Servaes 2002). Josephi (2009) argues that journalism courses are 
hard to design as the field's focus moves back and forth from imparting skills to ritual building in the field. There is a notion that learning via apprenticeship was used to enrich technical skills (Bromley 1997; Colle 2008) and to know contextual use of the discipline (Curran 2005; UNESCO 2007).

Moreover, looking into the classroom syllabi is also of importance if the DevCom agenda is to be scrutinised. Syllabi have been seen as one of the ways in which academic programs are robustly taught (Palmer et al. 2014). Faculty members use a class syllabus as basis for learning (Heffernan 2001; Parkes and Harris 2002) and competence (Petrovici and Masari 2014). Quality assurance of content, after all, is verified using a syllabus' affective and effective learning outcomes and goals (Sabol and DeWester 2005; Mintu-Wimsatt et al. 2010). Syllabi are, therefore, important tools in the investigation of a program's sense and direction (Waddington 2010).

Given these accounts, it is imperative to look into the themes of development journalism that are being disseminated and tutored to the wouldbe DevCom practitioners. Since the discursive power of the teachers is one of the potent means of perpetuating the discourse of development in the academe, then it is crucial to analyse the manner of constructing development from the vantage point of the educators.

\section{Theoretical Frameworks}

This paper has used two theoretical anchors. The first theory stems from the proposal of Xiaoge (2009) on the indicators and typologies of development journalism. Xiaoge claims that in order to observe how development journalism works, it must be seen from a three-pro mapping approach/types namely: pro-process, pro-participation, and pro-government. Pro-process functions articulate concepts of development by providing definitions, characteristics and background to the notion of development. Secondly, a journalistic act is said to be pro-participation if it is practical, praxis-driven and causes sense of empowerment among the practitioners. Lastly, a development journalism output is pro-government if it is used as a mouthpiece of those in power, for the purpose of creating information for the consumption of an audience.

The bottom line here is that development journalism is understood as part of the mediation process that bridges development to its desired stakeholders. The author argues further of a link that connects these three approaches to how institutions practice the field. Xiaoge further asserted that the pro-process and pro-participation approaches are the root causes of this type of journalism while the pro-government approach is seen as a result of the strong ties between government and the media, all in the name of nation building. 
On the other hand, this paper also used Arturo Escobar's (1995) notion of post-development. Escobar argued that there is more to development than economic benefits. Aimed at changing the approaches to development, Escobar proposed that alternatives to development must be considered. These include a rejection, resistance, recall and a restructuring of the paradigm of development. Escobar pointed out that in order to reconstruct the third world, alternatives from the grassroots, local knowledge, and even popular culture must be articulated in the mainstream discourse of development. The capacity to resist development, Escobar pointed out, would lead to the construction of new identities. Eventually, if the alternatives are considered, then a restructuring of development practices may happen and a change in the political economies of truth will emerge.

In this study, the researcher gauged whether the notions of development from the selected syllabi from the Department of Development Journalism, CDC, University of the Philippines Los Baños (UPLB) advocate the approaches mentioned by Xiaoge and even extend to the discourse of Escobar's postdevelopment. Since the syllabi and the educators are representations of the discourse of the academic institutions to which they belong, it was interesting to see how development is discursively constructed and/or co-created at the DevJourn department, as well as to see how development journalists/educators reinforce, mediate, and/or challenge the existing discourses of development, especially in the Philippines.

\section{METHODS AND PROCEDURES}

The main research technique that was used is the document thematic analysis to see how the syllabi were constructed to enunciate the discourse of development. Syllabi were identified as pro-process if the course description, goals, topics, and references point to the ideas of providing training both hard and soft communication and interpersonal skills for nation building and development. Syllabi were used as units of analysis as these documents house the content, manner of delivery, list of requirements and references. The research argues that what is written in the syllabi reflect framed ways of looking into the teaching of development. Moreover, the courses were assessed if they fit the constructs listed in the table below. Secondly, courses were classified as pro-participation if the syllabi would allow students to act as agents of empowerment, as real watchdogs in the field, and as reporters of transparency of development services. The courses were classified to belong in this type if the course content would require the students to exercise their 
skills in actual development projects in communities. Lastly, the courses are classified as pro-government if the content and delivery allow the learners to tie up with government projects, report on the impact of government development missions, and help in the constructive cooperation between the people and the government.

Listed in the following are sample words, statements and concepts that helped the researcher code the mentioned constructs.

Table 1: Summary matrix of codes used.

\begin{tabular}{|c|c|}
\hline $\begin{array}{l}\text { Constructs of } \\
\text { development }\end{array}$ & \\
\hline Pro-process & $\begin{array}{l}\text { Definitions of development and communication } \\
\text { Characteristics of development and communication } \\
\text { Providing the language for development } \\
\text { Introductory topics to social, economic and cultural developments }\end{array}$ \\
\hline Pro-participation & $\begin{array}{l}\text { Situational values of development } \\
\text { Contribution of the ordinary people } \\
\text { Contextual use of development power to communities } \\
\text { People as active recipients of development } \\
\text { Actual implementation of development via communication plans }\end{array}$ \\
\hline Pro-government & $\begin{array}{l}\text { Development communicators, especially journalists, as nation builders } \\
\text { Development journalists as government partners } \\
\text { Journalists as agents of empowerment }\end{array}$ \\
\hline
\end{tabular}

Escobar's notions on post-development were also verified using the syllabi's course descriptions, content and references. The researcher looked at the themes of development posted by the sample courses and check if articulations on alternatives to development such as the highlighting of grassroots and local knowledge, as well as restructured development discourses from the local, are present. The gathered data were arranged in a dendrogram (Drout and Smith 2012) to know the most significant content from the syllabi and the significant statements mentioned by the informants.

\section{RESULTS AND DISCUSSION}

The study focused on analysing eight syllabi from the Department of Development Journalism. Although the Bachelor of Science (BS) DevCom program has adapted the generalist framework, the sample syllabi are framed and taught under the vision and framework that the Department of Development Journalism has declared in its website. Resting on the 
assumption that DevCom and, more specifically, DevJourn aims to provide a training ground for empowering communicators and communities, the courses offered seem to be aimed at providing the standards for instruction, research, and extension while, at the same time, empowering individuals and their localities. Interestingly, the courses fit the two molds of Xiaoge's (2009) typologies and indicators namely: pro-process and pro-participation. No course in the sample is framed to be pro-government. Furthermore, the syllabi contained traces of Escobar's notions of alternatives to development. The alternative discourses, I argue, are not highlighted in the syllabi as the courses and the faculty themselves have admitted that the courses are still in the process of theorising about their discourse of development.

\section{Pro-process Courses}

Introductory courses like DEVC 10 (Introduction to Development Communication) and DEVC 11 (Introduction to Mass Media Writing) belong to the "pro-process" category as these courses articulate concepts of development, communication and development communication. It also points to the difference of DevCom from any communication programs. For one, the course backgrounder for DEVC 10 highlights that the field of DevCom is supposed to "empower and enrich the lives of the marginalised and the least served sectors" (Department of Development Journalism 2014a: 3). As a course that focuses on concepts, theories, principles, and practice of communication in development, it looks at how learners are able to identify concepts such as development and underdevelopment, discuss the principles of development and communication, define the domains of field and identify the roles that it plays in development work. Interestingly, the course provides dominant and alternative paradigms and trends with regards development and underdevelopment by highlighting worldwide issues such as unemployment, inequality, degradation, poverty and the like. It also talks about the grand narratives and the imposed parameters of development such as the Millennium Development Goals and the Philippine Development Plan. The course modules highlight how DevCom can mediate in the process of empowering the community by providing core values, domains and meaning to the agenda of action towards the eradication of problems such as lack of empowerment and education of the local. Most of the references that are used in the course are local literatures that were penned by the founders and/or teachers of DevCom in UPLB. The course seems to be pro-process since it allows a learner to look at his or her skills before s/he can embark on the field of DevCom. 
Another introductory course, DEVC 11, highlights the language and skills necessary for learners to write for various media. In the said course, students are taught principles on the tri and emerging media. Simulations are taught with the agenda to "promote development" (Department of Development Journalism 2014b: 2). Interestingly, the course also provides the necessary training for one to mark his or her distinction as a DevCom practitioner by exposing him/herself to the fundamental cores: development journalism, community broadcasting, educational communication, and science communication. Perhaps because the students have been exposed to DEVC 10 - a course prerequisite - no topic in the syllabus has touched on how the media relate to development. Also, there were only four out of seventeen references that talked about the practice of mass media in the local setting. Still, the course is heavy on educating the process of immersing in the field of mass communication, perhaps with development as an overarching core concept.

DEVC 80 (Communication and Society) is also pro-process in the sense that it surveys and looks at the relationship between communication, media and the people. As an appreciation course, this deals with ethics, rights and responsibilities of the communication profession to the immediate society. The course's strength lies on how it is grounded on the development of Philippine media. Its weakness appears to be on how it only looks at communication and media practices, without the flavour of development that the course promises to its learners. This seems to be the case since the course content provides a scan of the history of media. Perhaps, when the content is coupled with delivery from the expert/teacher, then the development discourse is sustained.

Lastly, DEVC 125 (Writing and Reporting for Development) provides the biggest promise to connect communication and development as indicated in its title. Taking off from the idea that development can be communicated in various platforms, this course envisions its learners to be trained not just in basic knowledge and skills in news and features writing and reporting but also to arm the students with the processes in communicating for development and social change. As a preparatory course for actual practice, the students are expected to be "knowledgeable on theories and concepts of reportage in various platforms and demonstrate certain skills in multi-platform reportage" (Department of Development Journalism 2014c: 2). On one hand, the course starts with a review of the key concepts in development, community and reporting for development. This appears to show that the tutoring in the writing and reporting of development concerns would be focused on how communities become beats and look at people in communities as partners in the creation 
of information that is vital for such public. On the other hand, the references appear to be too broad to focus on the community empowerment it promises. Furthermore, the course syllabus provides no specific sample cases on how writing and reporting can be used for community development, at least in the Philippines setting.

Still, these four courses appear to focus on communicative and developmental processes that would allow students to know the rudiments of the program. The courses are thematically similar in the sense that these four focused on training the students about media and communication skills while, at the same time, anchor such tutelage to the construct of development that the founders of DevCom have laid down.

I wonder, however, if there is an overarching concept of the development paradigm that is present and binding throughout the courses of DevJourn at UPLB? If there is already an epistemological thread of what DevCom is, then there could be a more resonant tone to the processes that are amplified by DevCom. Perhaps the ambiguity lies on the way development has been constructed in the DevCom paradigm. Escobar warned that at times, the development discourse might be legitimised not from the perspective of the recipients but from the structures of knowledge that create these modes of development. Also, the status of certainty of development from the eyes of those who construct development seems to be powerfully cemented in the discourse of DevJourn at UPLB. This can be seen on the ways the core courses have included the millennium development goals, necessary expertise of communication practitioners before entering the "field," and assuming certain level of proficiency before a practitioner can empower a community.

\section{Pro-participation Courses}

Four of the eight courses provided by the Department of Development Journalism are focused on providing students with actual practices of empowerment. These courses are able to provide explanations and discussions on principles and theories of communication and media production. Additionally, the courses allow the students to carry out, apply, develop and produce materials for certain development projects.

Firstly, Interpersonal Communication in Development (DEVC 70) connects participatory communication methods to various areas of development work such as transfer of technology, research, community organising and facilitation. Exercises and fieldwork activities are built in the course to assure that students get a hands-on experience on various levels such as the identification of a problem of a community, problem or conflict 
resolution, and orientation to certain prescribed solutions. The course content is in sync with the claim that DevCom is praxis. Furthermore, it provides five Filipino-based references on how interpersonal communication can be best taught in the Philippines setting.

Secondly, the Participatory Development Journalism (DEVC 126) course is supposed to be the practical component of a skills-based course entitled DEVC 125. The point of this course is to let the students absorb the concepts and see how these are constructed in the field. The course contents allow the learner to be trained on the ethical practice of participatory development journalism. Its battle cry is to provide the learners with the necessary skills to use and integrate both the legacy and the emerging media in producing stories that involve and engage the community. The course does not only teach how stories can be made in-depth but also tutor on the proper facilitation-based skills to elicit and involve individuals in the community in telling their stories. Captivatingly, the course provides the proper methods and techniques in participatory research to enable the community to share its accounts, provide their community-centred information and perform their skills in community reportage. This is done in order to instil accountability and public service that stem from their consciousness. In this setting, the role of the facilitator/student is not to only gather information but to empower the community to tell versions of the truths. The course also ensures that before students are brought to the field, they are taught the processes of analysing cases for participatory development journalism, information gathering, storytelling, in-depth interviewing, moderating a panel, live reporting, and analysing cases of malpractice in community reportage inside "laboratories." It seems, however, that in spite of the optimistic framing of the course, there appears to be a problem on the type of development that the course is advocating as the course leans towards the training of the skills more than the analysis of the developmental purposes for the skills. I argue about this as seen from the minimal number of references and exercises that highlight development from the list of books that are provided in the syllabus.

Courses such as Multimedia Materials Planning and Design (DEVC 135) and Multi-media Materials Production and Management (DEVC 136) are classified too as pro-participation because of the expected outputs at the end of the one-semester stay in the courses. DEVC 135 focuses on developing plans and prototype media materials and assessing these plans for various media types. The course provides lectures on how media materials in the context of development communication. It also highlights the use of media types such as aural, publications, audio-visual and multi-media in the context of a partner 
agency. These agencies may be government and/or non-government agencies (NGOs). On the other hand, DEVC 136 is the production component of the multi-media materials course for development. As a practical course, it aims to not only describe and explain the concepts and principles of media production and media materials but also to actually produce selected communication media and materials for development. From the basic steps in production of various media to various steps in pre-testing, monitoring, and evaluating the outputs, the course teaches the students how to educate the community of the processes of media production. This practical nature of the course is seen on the laboratory requirements where students are exposed to community radio programs, print and online community newspaper and community cable TV program.

The four courses that are classified as pro-participation seem to provide the students not only the necessary skills that allow them to engage in communication production but also are armed in participatory methods to empower the community to co-produce community-centred stories. Moreover, the courses are designed to train the students to become agents of empowerment. The students, playing as actors for development work, are trained to contain the adequate skills and know-how in letting the grassroots define how they would write, report and broadcast about their own concerns. Furthermore, the course seems to suggest that with the perceived openness between the development communicators and the community, there is an orientation that the stories of the people are highlighted and given emphasis. Interestingly, no course syllabus has the flavour of being pro-government. Perhaps as a faithful reminder to abandon the unpalatable modernist agenda of the Marcos times that coincided with the birth of DevCom (Cagasan et al. 2008: 48), the courses that are taught now highlight the participatory nature of communication-a characteristic that has been with the program since its conception in 1971 (Quebral 2012; Cagasan et al. 2008). Furthermore, even if there are existing partnerships between the government and the College, the faculty members are keen on identifying and exemplifying the moral development agenda that Quebral has put forward in the past.

\section{Problematising the Development Discourse}

If one would look for alternatives to the discourse of development, there is little to be found in the DevCom syllabi. It seems that the reviewed syllabi are focused on increasing the necessary skills of a communication practitioner who approaches communication problems with the flavour of participation. The courses seem to suggest that with the proper facilitation of participative 
action, development can be attained. It fails to recognise two conceptual blocks to its call: What kind of development is the program mediating? Also, what kind of development is DevJourn participating in?

Although renowned work of Escobar (1995) and local literature on people's development (Morales 1990) and people's empowerment (Navarro 1993) are part of the references for DevCom's introductory courses, these alternative discourses are not sustained in the core courses of the program. Admittedly, the faculty members mentioned during the interview that there is much to discuss about the inclusion of various voices on development in the DevCom program. In the end, there seems to be an agreement between the two informants that the program has yet to have an analytical stance that would harmonise its skills-training perspective.

I argue, as a support suggestion to the point mentioned above, that DevCom must be critical to development. It appears that the courses that were reviewed in this paper focused on paving the process and the participation of communication in mediating development but it does not put forward the essential question: What kind of development is the program catering to? Although this question has been answered by looking at the past, perhaps it would be fruitful too to problematise how development is to be cohesively discussed in the syllabi of the Department. Guieb (2015), in his syllabus on Media 303: Discourses on Development, mentioned that discourses of development from the past must be surveyed and examined in various settings in order to explore interactions of social justice and empowerment. Perhaps if faculty members can become critics of the development communication discourses within the field of DevCom, then there can be healthier discussions on what the field is and can be.

Another suggestion on how the discourse of development can be properly strengthened is through the constant reiteration of where the DevCom paradigm comes from. Quebral has already provided the valuable spring board-"communication should follow where development leads." This has to be articulated not only in principle but also in practices inside the classroom. This should be a commitment and should be made even clearer especially in course objectives, topics, activities, and even in lists of references of the courses. Cagasan et al. (2008) already provided the history of how DevCom has been constructed. As part of an on-going agenda to reconstruct the DevCom identity, one has to marry the past "development" constructs of improvement, goal and process to how it wants to play its social agent face in the future. It appears that the right time has come for the current faculty and staff to develop a unified thrust for what it would want to achieve as a communication tradition. 
Perhaps it would also want to consider the still hanging suggestion of Librero (2008): to sit down and talk about the DevCom meta-frame. One should constantly ask: What really is the DevCom theory? Given all the researches and extension capacities of the College, there are already healthy strands of empirical and discursive bases as to how the field can claim its domain. One cannot, therefore, escape the agenda of theorising to strengthen the cornerstone of the claim. I argue that by looking at the epistemological and ontological nature of DevCom, one can now reinforce its spirit inside the syllabi. After all, academic institutions must theorise in order to fortify their core philosophies. Given the extension expertise and strong faculty profile, DevCom will have no problem looking for its theoretical ground within its robust extension tradition.

\section{CONCLUSION}

The list of reviewed DevCom syllabi follows a top-down learning frame and approach. As such, development is seen from the eyes of experts and experts-in-training. However, the study argues that this approach is not seen as a limitation as DevCom's syllabi are classified as either pro-process or proparticipation. Moreover, it appears that DevJourn, a component of DevCom in the Philippines, still has to be theoretically anchored, as there are no syllabi content yet on the frameworks that would bind the program. Findings of this paper also revealed that syllabi from DevCom do not have post-development discourse yet.

The DevCom programs in various institutions in and outside the Philippines are known for their development extension services. Governments, international agencies, and non-government organisations tap their graduates to serve as eyes and arms in channelling social change. The concern, however, is on how these programs package their agenda for development. Apparently, the research has indicated that it is important to scrutinise how the development agenda is portrayed in the syllabi. Although administrators and faculty members have framed their development discourse as pro-process and pro-participation, still the courses are using the top-down approach where the development communication students and practitioners are seen as source of experts in development. Moreover, the syllabi lacked the post-development discourse frame where students are supposed to be taught that "development" is not an aide from the outside but a socially constructed reality of the communities - the bottom-up approach to social change. 
As limitations of this research, the research, however, did not look into the possibility of "pro-government" constructs as indicated in the syllabi's content and references. Perhaps, this may arise in the classroom discussions with the faculty members. Future studies may look into how these constructs are lived inside classroom discussions. Moreover, it did not look into the effects of DevCom's development discourse to its students. Future researches should look into the attitude; behaviour and practices of these DevCom students to further strengthen the development communication brand.

As an outsider looking in, the researcher also cites that the higher education institutions offering DevCom must revisit their set of syllabi to look into how development is channelled and incorporated in the content of the course. There should also be constant collaboration among colleges and universities to define and bind the DevCom meta-frame as the field understands and provide solutions to poverty issues in local and global settings.

\section{NOTES}

* Jonalou S. Labor is a PhD Communication candidate at the University of the Philippines. He teaches communication theory, management and research in the undergraduate and graduate programs of communication. He has published works in topics such as educational technology, branding, media practice and critical communication.

\section{REFERENCES}

Anderson, L. W. et al. 2001. A taxonomy for learning, teaching, and assessing: A revision of Bloom's taxonomy of educational objectives. New York: Longman.

Boafo, S. T. K., ed. 1991. Module on Development Communication 1. Nairobi: African Council for Communication Education.

Bromley, M. 1997. The end of journalism? Changes in workplace practices in the press and broadcasting in the 1990s. In A journalism reader, ed. Bromley, M. and O'Malley, T. 330-150. London: Routledge.

Cagasan, E. et al. 2008. Constructs of "development" among CDC Faculty and in student research studies. Philippine Journal of Development Communication 1 (1): 37-74.

Colle, R. D. 2008. Threads of development communication. In Communication for development and social change, ed. Servaes, J. Los Angeles: Sage, https://doi. org/10.4135/9788132108474.n7.

College of Development Communication, University of the Philippines Los Banos. 2015. Mission and vision. http://www.devcom.edu.ph (accessed 25 April 2015).

Cornwall, A. and Eade, D., eds. 2010. Deconstructing development discourse: Buzzwords and fuzzwords. London: Practical Action Publishing and Oxfam GB. 
Curran, J. 2005. Foreword. In Making journalists, ed. de Burgh, H., xi-xv. London: Routledge.

Della Faille, D. 2011. Discourse analysis in international development studies: Mapping some contemporary contributions. Journal of Multicultural Discourses 6 (3): 215235. http://dx.doi.org/10.1080/17447143.2011.594512

Department of Development Journalism. 2014a. Course guide for DEVC 10: Introduction to Development Communication [syllabus]. Manila: College of Development Communication, University of the Philippines Los Baños.

Department of Development Journalism. 2014b. DEVC 11 course guide: Introduction to mass media writing [syllabus]. Manila: College of Development Communication, University of the Philippines Los Baños.

Department of Development Journalism. 2014c. Course guide for DEVC 125: Writing and reporting for development [syllabus]. Manila: College of Development Communication, University of the Philippines Los Baños.

Department of Development Journalism. 2015. University of the Philippines Los Banos. 2015. Mission. http://www.devcom.edu.ph (accessed 25 April 2015).

Djokotoe, E. 2013. Ten practical tips for covering development. Washington, DC: International Center for Journalists.

Domatob, J. K. and Hall, S. W. 1983. Development journalism in Black Africa. Gazette 31 (1): 9-33, https://doi.org/10.1177/001654928303100102.

Drout, M. and Smith, L. 2012. How to read a dendrogram. Wheaton College. http:// wheatoncollege.edu/lexomics/files/2012/08/How-to-Read-a-Dendrogram-WebReady.pdf (accessed 10 December 2014).

Edeani, D. 1993. Role of development journalism in Nigeria's development. Gazette 52 (2): 123-143, https://doi.org/10.1177/001654929305200204.

Escobar, A. 1995. Encountering development: The making and unmaking of the third world. Princeton: Princeton University Press.

Fink, L. D. 2013. Creating significant learning experiences: An integrated approach to designing college courses, 2nd ed. San-Francisco, CA: Jossey-Bass.

Grossenbacher, R. 1988. Journalismus in Entwicklungsländern [Journalism in development countries]. Wien: Böhlau.

Guieb, E. III. 2015. Syllabus of Media 303: Media and discourses on development. Diliman: Department of Broadcast Communication, College of Mass Communication.

Heffernan, K. 2001. Fundamentals of service-learning course construction. Rhode Island: Campus Compact.

Josephi, B. 2009. Journalism education. In The handbook of journalism studies, ed. WahlJorgensen, K. and Hanitzsch, T., 42-56. Routledge: Taylor and Francis.

Lagerway, C. 1990. Monographs on development communication. Manila: Communication Foundation for Asia.

Lawrence, T. B. 2008. Power, institutions, and organizations. In Sage handbook of organizational institutionalism, ed. Greenwood, R. et al., 170-197. Los Angeles: Sage Publications, https://doi.org/10.4135/9781849200387.n7.

Librero, F. 2008. Quo vadis, Development Communication? Thoughts of the practice of DevCom in a knowledge society. The Philippine Journal of Development Communication 1 (1): 186-197. 
Lundell, D. B. and Higbee, J. L. 2001. Theoretical perspectives in development education. Center for Research on Developmental Education and Urban Literacy, General College, University of Minnesota, Minneapolis, MN.

Mefalopulos, P. 2008. Development communication sourcebook: Broadening the boundaries of communication. Paris: World Bank Publications, https://doi.org/10.1596/978-08213-7522-8.

Mintu-Wimsatt, A., Kernek, C. and Lozada, H. 2010. Netiquette: Make it part of your syllabus. MERLOT Journal of Online Learning and Teaching 6 (1): 264-267.

Morales, H. 1990. A call for people's development: Selected speeches form 1986-89. Quezon City: NCCP.

Niedermeier, F. and Pohlenz, P. 2016. State of play and development needs: Higher education quality assurance in the ASEAN Region. Jakarta: DAAD.

Navarro, R. L. (1993). Towards people empowerment: GO-NGO collaboration in agricultural development. Manila: Philippine Rice Research Institute

Pakistan Higher Education Commission. n.d. Development journalism: Concept and process http://prr.hec.gov.pk/Chapters/3702H-6.pdf (accessed 15 April 2016).

Palmer, M. S., Bach, D. J. and Streifer, A. C. 2014. Measuring the promise: A learningfocused syllabus rubric. To Improve the Academy: A Journal of Educational Development 33 (1), 14-36.

Parkes, J. and Harris, M. 2002. The purposes of a syllabus. College Teaching 50 (2): 55-61, https://doi.org/10.1080/87567550209595875.

Petrovici, C. and Masari, G-A. 2014. Content analysis of syllabus for students of kindergarten and primary school pedagogy according to the professional competence. Moscow: Elsevier.

Quebral, N. 2012. Development communication primer. Kuala Lumpur: Southbound.

Rolle, M. R. F. 2016. 1st UPLB legacy lecture features Nora C. Quebral. University of the Philippines Los Banos. http://uplb.edu.ph/341-1st-uplb-legacy-lecture-featuresnora-c-quebral (accessed 15 July 2016).

Sabol, D. and DeWester, J. 2005. Content analysis of course syllabi and assignments for IU ePort pilot. Office for Professional Development, Indiana University-Purdue University Indianapolis.

Singhal, A. and Rogers, E. 2012. Entertainment-education: A communication strategy for social change. New York: Routledge.

Servaes, J. 1995. Development communication - for whom and for what? Communicatio 21 (1): 39-49. . ed. 2002. Approaches to development communication. Paris: UNESCO . ed. 2008. Communication for development and social change. SAGE: London.

UNESCO. 2007. Model curricula for journalism education for developing countries and emerging democracies. Paris: UNESCO.

Thomas, P. 2008. Communication and the persistence of poverty: The need for a return to basics. In Communication for development and social change, ed. Servaes, J. Sage: Los Angeles, https://doi.org/10.4135/9788132108474.n2.

Vilanilam, J. V. 1975. Developmental news in two leading Indian newspapers. Media Asia 2 (1): 37-40, https://doi.org/10.1080/01296612.1975.11725838. 
Waddington, S. 2010. Syllabuschange, studentlearning and teacherexperiences. NewZealand Geographer 66: 189-195, https://doi.org/10.1111/j.1745-7939.2010.01186.x

Waisbord, S. 2001. Family tree of theories, methodologies and strategies in Development Communication. The Rockefeller Foundation. http://www. communicationforsocialchange.org/pdf/familytree.pdf (accessed 25 July 2015).

White, R. A. 2004. Is 'empowerment' the answer? Current theory and research on development communication. Gazette 66 (1), 7-24, https://doi.org/10.1177/ 0016549204039939.

Wimmer, J. and Wolf, S. 2005. Development journalism out of date? An analysis of its significance in journalism education at African universities. University of Munich. http://epub.ub.uni-muenchen.de/archive/00000647/ (accessed 26 April 2015).

Xiaoge, X. 2009. Examining development journalism: Indicators and typologies. Singapore: Wee Kim Wee School of Communication and Information, Nanyang Technological University.

Wahl-Jorgensen, K. and Hanitzsch, T. 2009. The handbook of journalism studies. New York: Routledge. 